\title{
Upregulation of Igf and Wnt signalling associated genes in pleomorphic adenomas of the salivary glands in PLAG1 transgenic mice
}

\author{
JEROEN DECLERCQ ${ }^{1}$, FREDERIK VAN DYCK ${ }^{1}$, BOUDEWIJN VAN DAMME ${ }^{2}$ and WIM J.M. VAN DE VEN ${ }^{1}$ \\ ${ }^{1}$ Laboratory for Molecular Oncology, Department of Human Genetics; ${ }^{2}$ Department of Morphology \\ and Molecular Pathology, University of Leuven, Leuven, Belgium
}

Received October 11, 2007; Accepted December 5, 2007

\begin{abstract}
The Pleomorphic adenoma gene 1 (PLAG1) is involved in various human neoplasias, including pleomorphic adenomas of the salivary glands. Moreover, the oncogenic role of PLAG1 was clearly demonstrated in two independent $P L A G 1$ transgenic mouse founders, in which PLAG1 expression could be targeted to different tissues using the Cre/loxP system. MMTV-Cre-mediated targeted overexpression of PLAG1 in the salivary glands of double transgenic offspring mice, referred to as P1-MCre and P2-MCre mice, induced pleomorphic adenomas in this organ. $\operatorname{Igf} 2$, a genuine PLAG1 target gene, was highly upregulated in those tumours as well as in human pleomorphic adenomas of the salivary glands. These and previous observations in other PLAG1-induced tumours e.g. breast adenomyoepitheliomas emphasize the importance of Igf upregulation in such tumours. In this study, further evidence for the role of Igf2 in PLAG1induced tumourigenesis, is reported. Inactivation of $\operatorname{Igf} 2$ in P1-MCre mice leads to a significant delay in tumour development. Since tumour development is not fully abrogated by inactivation of $I g f 2$, other signalling pathways are likely to contribute to PLAG1-induced tumourigenesis as well. Further studies revealed that several genes such as H19, Dlkl, Gtl2, Igfbp2, Igfbp 3 and genes involved in Wnt signalling, such as Wnt6, Cyclin D1 and $\beta$-catenin are upregulated in P1-MCre mice in which $\operatorname{Igf} 2$ is inactivated. In conclusion, we clearly demonstrate upregulation of several genes associated with Igf and Wnt signalling in PLAG1-induced pleomorphic adenomas. Furthermore, inactivation of $I g f 2$ does not affect upregulation of genes associated with Wnt signalling, which might suggest that both signalling pathways are involved.
\end{abstract}

Correspondence to: Professor W.J.M. Van de Ven, Laboratory for Molecular Oncology, Department of Human Genetics, K.U. leuven, Herestraat 49/602, B-3000 Leuven, Belgium

E-mail: wim.vandeven@med.kuleuven.be

Key words: PLAG1 proto-oncogene, transgenic mouse strains, pleomorphic adenomas of the salivary glands, Wnt signalling associated genes, insulin-like growth factor 2

\section{Introduction}

Pleomorphic adenoma is the most common tumour in human salivary glands, accounting for about half of all neoplasms in this organ (1). About $84 \%$ of the pleomorphic adenomas occur in the parotid glands, $8 \%$ in the submandibular glands, $6.5 \%$ in the minor glands, and $0.5 \%$ in the sublingual glands (2).

Pleomorphic adenomas are slow growing, painless, encapsulated tumours that may become large if untreated. Larger lesions can have sites of necrosis, haemorrhage, focal calcification or occasionally ossification (3). Although these tumours are usually benign, they have the tendency to recur when inadequately excised. Moreover, $2-17 \%$ of the tumours can progress to malignancy and give rise to carcinoma ex pleomorphic adenoma (4-6).

Cytogenetically, pleomorphic adenomas of the salivary glands are well characterized, with several hundreds already karyotyped $(7,8)$. Four major cytogenetic subgroups can be distinguished (9). The first consists of tumours with $8 \mathrm{q} 12$ rearrangements $(39 \%)$. The second is composed of tumours with translocations involving chromosomal region $12 \mathrm{q} 14-15$ $(8 \%)$. The third is composed of tumours with various nonrecurrent translocations $(23 \%)$ not involving chromosomal region $8 \mathrm{q} 12$ or $12 \mathrm{q} 14-15$. The last subgroup consists of tumours with an apparently normal karyotype (30\%). It is clear that the translocations involving $8 \mathrm{q} 12$ and $12 \mathrm{q} 14-15$ are frequently encountered in pleomorphic adenomas of the salivary glands. By positional cloning, we identified the genes involved in those translocations. The high mobility group protein $\mathrm{C}$ (HMGI-C, now known as $H M G A 2)$ gene was found to be affected in tumours with 12q14-15 translocations (10) whereas the Pleomorphic adenoma gene 1 (PLAG1) was found to be affected in tumours with $8 \mathrm{q} 12$ translocations (11). The most common abnormality in the latter cases is a $\mathrm{t}(3 ; 8)(\mathrm{p} 21 ; \mathrm{q} 12)$ translocation, found in almost half of these. The translocation results in promoter swapping between PLAG1 and CTNNB1 (the gene for $ß$-catenin). As a result of the $\mathrm{t}(3 ; 8)(\mathrm{p} 21 ; \mathrm{q} 12)$ translocation, the coding sequences of PLAG1 are brought under the control of the 5' regulatory sequences of the $C T N N B 1$ gene, and vice versa. The regulation of the expression of both genes is very different. Whereas, the CTNNB1 gene is highly, ubiquitously, and constitutively expressed, PLAG1 has high overall developmental expression 
levels, which drop shortly after birth (12). As a consequence, the above-sited $\mathrm{t}(3 ; 8)$ translocation leads to an aberrant activation of PLAG1. In addition to the CTNNB1-PLAG1 fusion gene, three alternative fusion genes have been identified in pleomorphic adenomas. LIFR-PLAG1 is found in tumours with $\mathrm{t}(5 ; 8)(\mathrm{p} 13 ; \mathrm{q} 12)(13)$, whereas TCEA1-PLAG1 (also known as $S I I$ ) (14) and CHCHD7-PLAG1 (15) both result from cryptic rearrangements in tumours with a normal karyotype. Analysis of the structure and function of the PLAG1 fusion partners have not revealed any obvious similarities besides their constitutive expression pattern, or at least their expression in the cells or tissues from which the tumours are thought to originate. Therefore, it has been suggested that the most important function of the fusion partner genes is most likely to provide an active promoter that induces ectopic expression of PLAG1 (9).

In addition to pleomorphic adenomas, ectopic expression of PLAG1 is also found in lipoblastomas (16-18), hepatoblastomas (19), and AML $(20,21)$. The oncogenic capacity of PLAG1 has been demonstrated in vitro, i.e. in cell lines that were retrovirally transduced with PLAGI (22), and recently, in vivo in mouse models $(23,24)$. Whereas Zhao and co-workers generated classical, non-conditional transgenic mouse strains (24), we developed two independent PLAG1 transgenic mouse strains, PTMS1 and PTMS2, in which activation of overexpression of the transgene as well as the tissue distribution of such overexpression can be manipulated, by Cre-mediated activation and targeted expression, respectively (23). To study the consequences of genetically engineered PLAG1 expression in the salivary glands, the two independent PLAG1 transgenic mouse strains were intercrossed with B6129-Tgn(MMTVLTR/Cre)1Mam (MMTV-Cre) transgenic mice $(25,26)$. The resulting double transgenic offspring mice, referred to as P1MCre and P2-MCre mice, developed pleomorphic adenomas of the salivary glands with a prevalence of $100 \%$ (within 5 weeks) and $6 \%$ (after several months), respectively (23).

Previous microarray studies, including comparative gene expression profiling in human and mouse salivary gland tumours (27), revealed genes that are consistently induced by PLAG1. Of interest to note is the upregulation of genes functioning in Igf (mouse) and IGF (human) signalling. In validation experiments, it has already been proven for instance for IGF-II that it constitutes a genuine direct target gene of PLAG1 (28).

The upregulation of Igf2 in pleomorphic adenomas of the salivary glands thus suggests a contributing role of Igf2 in the $P L A G 1$-induced tumourigenesis. To study the precise impact of Igf2 upregulation on PLAG1-induced tumour formation, we intercrossed P1-MCre mice with Igf2 knockout mice $(29,30)$. The investigation focused on monitoring tumour development, histological analysis of tumour lesions, and upregulation of expression of genes associated with signalling pathways.

\section{Materials and methods}

Generation of P1-MCre and various P1-MCre-Igf2 compound transgenic/knockout mice. The generation of the PLAG1 transgenic founder line, PTMS1, has been reported previously (23). To target PLAG1 expression to the salivary glands, this founder was crossed with B6129-Tgn(MMTV-LTR/Cre)1Mam transgenic mice (MMMTV-Cre) (Jackson's Laboratories, USA) (25), resulting in P1-MCre offspring. In order to generate compound transgenic/knockout mice involving PLAG1, Cre, and $\operatorname{Ig} f 2, \operatorname{Ig} 2^{p-/ m-}$ mice $(29,30)$ were crossed with PTMS1 mice, and MMTV-Cre mice with $I g f 2^{p-/ m-}$ mice to generate PI-Igf $2^{p-/ m+}$ and MMTV-Cre-Igf $2^{p-l m+}$ offspring, respectively. Mating of those compound heterozygous offspring yielded various genotypes, including Pl-MCre-Igf $2^{p-/ m-}, P 1-M C r e-I g f 2^{p-/ m+}$, Pl-MCre-Igf $2^{p+/ m-}$ and P1-MCre-Igf $2^{p+/ m+}$ mice. These offspring mice were used in further breedings to expand colonies, necessary for further analysis of the impact of $\operatorname{Igf} 2$ inactivation on tumour formation.

Genotyping of genetically modified mice by PCR analysis. Genotyping of candidate PLAG1 founders was performed by PCR analysis of tail DNA using oligonucleotide primers POS1599 (5'-TTCTCAAGCATCGTCATCAT-3') and B-globin (5'-AAAATTCCAACACACTATTGC-3'). For genotyping of the various genetically modified mice, gene-specific primers were designed for the following genes: Cre (forward: 5'-CCTG TTTTGCACGTTCACCG-3' and reverse: 5'-ATGCTTCTG TCCGTTTGCCG-3'), Igf2 wild-type allele (forward: 5'-GTA CCAATGGGGATCCCAGTG-3' and reverse: 5'-GCGGTC CGAACAGACAAACTG-3') and the Igf2 knockout allele (forward: 5'-TGCTCTGATGCCGCCGTGTT-3' and reverse: 5'-GTGCACTCTCAACCTGGCTGA-3'). All PCR reactions were performed at an annealing temperature of $58^{\circ} \mathrm{C}$ and involved 35 cycles except for the Igf 2 knockout allele, which involved 30 cycles. The annealing time was 40, 30, 30, and $50 \mathrm{sec}$ for PLAG1, Cre, the Igf2 wild-type allele, and Igf2 knockout allele, respectively.

Real-time quantitative PCR ( $Q R T-P C R)$. Total RNA from selected tissue specimens from normal tissue and tumours of the salivary glands was prepared using the NucleoSpin ${ }^{\circledR}$ RNA L kit, as described by the manufacturer, Macherey-Nagel. Total RNA $(5 \mu \mathrm{g})$ was reverse transcribed using random hexamer primers and M-MLV reverse transcriptase from Invitrogen (Merelbeke, Belgium). QRT-PCR was performed with the MyIQ system (Biorad). In all cases, 40 cycles of annealing/extension for $1 \mathrm{~min}$ at $60^{\circ} \mathrm{C}$ were performed. QRTPCR products were detected using SYBERGreen. QRT-PCR for $m t$-Atp6 was used as a reference to correct for sample quantity (forward primer: 5'-AAGCTCACTTGCCCAC TTCCTT-3' and reverse primer: 5'-GCTGTAAGCCGGA CTGCTAATG-3'). Gene-specific primers were designed for the following genes; PLAG1 (forward: 5'-CCACGTTTCCA TCAAGCTTTTC-3' and reverse: 5'-AGGCAGCCTGC ACCTGAG-3'), Igf2 (forward: 5'-TGTCTGTTCGGACC GCG-3' and reverse: 5'-GTTGGCACGGCTTGAAGG-3'), H19 (forward: 5'-AAGAGCTCGGACTGGAGACTAGG-3' and reverse: 5'-GGCACATCCACCTCTGCTG-3'), Dlk1 (forward: 5'-TGCGCGTCCTCTTGCTC-3' and reverse: 5'-CATTCAGCCCCATAGGTGCT-3'), Gtl2 (forward: 5'CTCCAACCCACTGCTTCCTG-3' and reverse: 5'-AGCGA GAGCCGTTCGATG-3'), Igfbp2 (forward: 5'-CCAACTGT GACAAGCATGGC-3' and reverse: 5'-GAGACATCTT GCACTGCTTAAGGTT-3'), Igfbp3 (forward: 5'-GCAGG CAGCCTAAGCACC-3' and reverse: 5'-GATGTTTCCT GGAGCAGGTTG-3'), Cyclin D1 (forward: 5'-CGAGGAG 


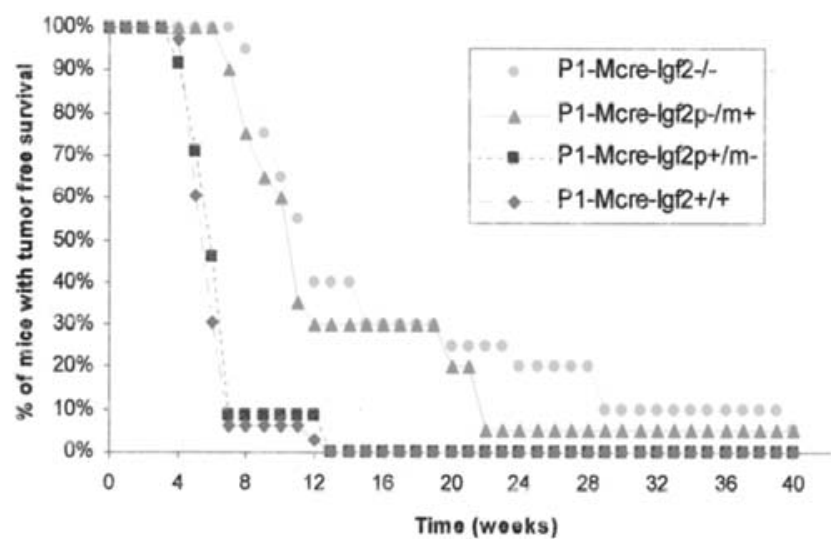

Figure 1. Percentage of PLAG1/Ig 2 genetically modified mice with tumourfree survival as detected by the absence of a macroscopically visible tumour mass in the ventral neck region in function of time. At least 20 mice were studied for each genotype.

CTGCTGCAAATG-3' and reverse: 5'-TTCCACTTGAG CTTGTTCACCA-3'), Wnt6 (forward: 5'-TGTCAGTTCCA GTTCCGTTTCC-3' and reverse: 5'-GCTGCGGTGATTG CAAACA-3') and $\beta$-catenin (forward: 5'-TTCAGATCTTA GCTTATGGCAATCAA-3' and reverse: 5'-TGGCCAGA ATGATGAGCTTG-3').

Western blot analysis. Salivary gland tumours of 8 - and 12-week-old P1-MCre mice, control littermate MMTV-Cre mice, and 30- and 37-week-old P1-MCre-Igf2 $2^{p-/ m-}$ mice were snap-frozen and stored at $-80^{\circ} \mathrm{C}$. Cryo-frozen tissue samples were homogenized in 5 volumes of suspension buffer, prepared by combining $0.1 \mathrm{M} \mathrm{NaCl}, 0.01 \mathrm{M}$ Tris/ $\mathrm{HCl} \mathrm{pH} 7.5,1 \mathrm{mM}$ EDTA pH 8.0 and protease inhibitors cocktail EDTA-free (Roche). An equal volume of $2 X$ SDS sample buffer, prepared by combining $20 \mathrm{ml} \mathrm{10 \%} \mathrm{SDS,} 10 \mathrm{ml}$ glycerol, $10 \mathrm{ml} 0.5 \mathrm{M}$ Tris/ $\mathrm{HCl} \mathrm{pH} \mathrm{6.8,} 60 \mathrm{ml} \mathrm{H}_{2} \mathrm{O}$, was added and the samples were heated for $10 \mathrm{~min}$ at $95^{\circ} \mathrm{C}$. The total protein concentration was determined using the BCA method and equal amounts of proteins were size-fractionated by SDS-Page. The proteins were transferred to a nitrocellulose membrane and Western blot analysis was performed, as described previously (23). Active- $\beta$-catenin and total $\beta$-catenin were detected with highly specific antibodies, clone 8E7 (Upstate) to detect active dephosphorylated $\beta$-catenin and antibody 610154 (BD Bioscience) to detect total $B$-catenin. As control for equal loading, actin was visualized using antibody A 5060 (Sigma).

\section{Results}

Evaluation of the role of Igf 2 in PLAG1-induced tumour development in P1-MCre mice. Previously, we generated two independent PLAG1 transgenic mouse lines, in which activation of overexpression of the transgene as well as the tissue distribution of such overexpression can be manipulated by Cre-mediated activation and targeted expression, respectively. These founder lines were intercrossed with $M M T V$-Cre mice to target the expression of the transgene mainly to the salivary glands. P1-MCre mice (100\%) developed pleomorphic adenomas of the salivary glands at 25-6 weeks. In contrast, only 6\% of the P2-MCre mice
Table I. Upregulation of PLAG1 target genes in pleomorphic adenomas of the salivary glands.

\begin{tabular}{lcc}
\hline Genes & P1-MCre-Igf2 $^{+/+}$ & P1-MCre-Igf2 $^{-/}$ \\
\hline Igf2 & $3422 \pm 1212$ & 0 \\
H19 & $948 \pm 328$ & $276 \pm 69$ \\
Dlk1 & $6165 \pm 1190$ & $3337 \pm 1180$ \\
Gtl2 & $79.5 \pm 0.3$ & $78.8 \pm 14$ \\
Igfbp2 & $17.4 \pm 4.6$ & $11.4 \pm 3.5$ \\
Igfbp3 & $16.5 \pm 4.4$ & $18.8 \pm 4.9$ \\
Cyclin D1 & $3.7 \pm 0.6$ & $3.2 \pm 0.7$ \\
Wnt6 & $46.8 \pm 10.8$ & $43.2 \pm 15.1$ \\
B-catenin & $2.1 \pm 0.4$ & $1.7 \pm 0.6^{\mathrm{a}}$ \\
\hline
\end{tabular}

Mean values \pm SEM of the fold upregulation of PLAG1 target genes in pleomorphic adenomas of the salivary glands of 5 P1-MCre$I g f 2^{p+/ m+}$ and 5 P1-MCre-Igf $2^{p-/ m-}$ mice as compared to normal salivary gland tissue of $5 M M T V-C r e$ and $5 M M T V-C r e-I g f 2^{p-/ m-}$ littermates, respectively. P-values are $<0.05$, except for ${ }^{\mathrm{a}} \mathrm{P}=0.2$.

developed similar tumours after several months. Igf 2 was highly upregulated in those PLAG1-induced pleomorphic adenomas of the salivary glands. Similarly, IGF-II was upregulated in human pleomorphic adenomas that expressed PLAG1 (28). IGF signalling is also implicated in many tumour types including, breast (31-33), colon (34) and liver (35). Altogether, those data indicate the Igf signalling might be important in PLAG1-induced tumourigenesis.

In this study, the role of Igf2 on PLAG1-induced tumourigenesis is further investigated. Due to the low tumour incidence and the long latency period in P2-MCre mice, we decided to investigate the role of Igf2 in PLAG1-induced tumourigenesis only in P1-MCre mice. Therefore, P1-MCre mice were crossed with $\operatorname{Ig} 22$ knockout mice $(29,30)$. Due to imprinting, only the paternal allele of $I g f 2$ is active, whereas the maternal allele is normally silenced via methylation. P1-MCre offspring, in which the paternal I $g f 2$ allele is knocked out or both $\operatorname{Ig} f 2$ alleles are knocked out, show a significant delay in the development of salivary gland tumours. This was assessed by determing the presence of macroscopically visible tumour masses in the ventral neck region (Fig. 1). As can be deduced from Fig. 1, for example $50 \%$ of the P1-MCre-Igf $2^{p-/ m-}$ mice and P1-MCre-Igf $2^{p-m+}$ mice developed large salivary gland tumours at $\sim 11-12$ weeks after birth. In contrast, $50 \%$ of the Pl-MCre-Igf $2^{p+/ m-}$ and Pl-MCre-Igf $2^{p+/ m+}$ mice showed macroscopically visible tumour masses already at $\sim 6$ weeks after birth (Fig. 1).

We have performed comparative histopathological studies to investigate whether or not particular differences could be found in tumour lesions with and without $I g f 2$ expression. These studies indicated that the histopathological features of the salivary gland tumours of $P 1-M C r e-\operatorname{Ig} 2^{p-/ m-}$ mice were similar to those observed in corresponding Pl-MCre-Igf $2^{p+/ m+}$ mice (Fig. 2). The salivary gland tumours studied all showed typical characteristics of pleomorphic adenomas. An overview of the pleomorphic character of the tumours of P1-MCre-Igf $2^{p-/ m-}$ 

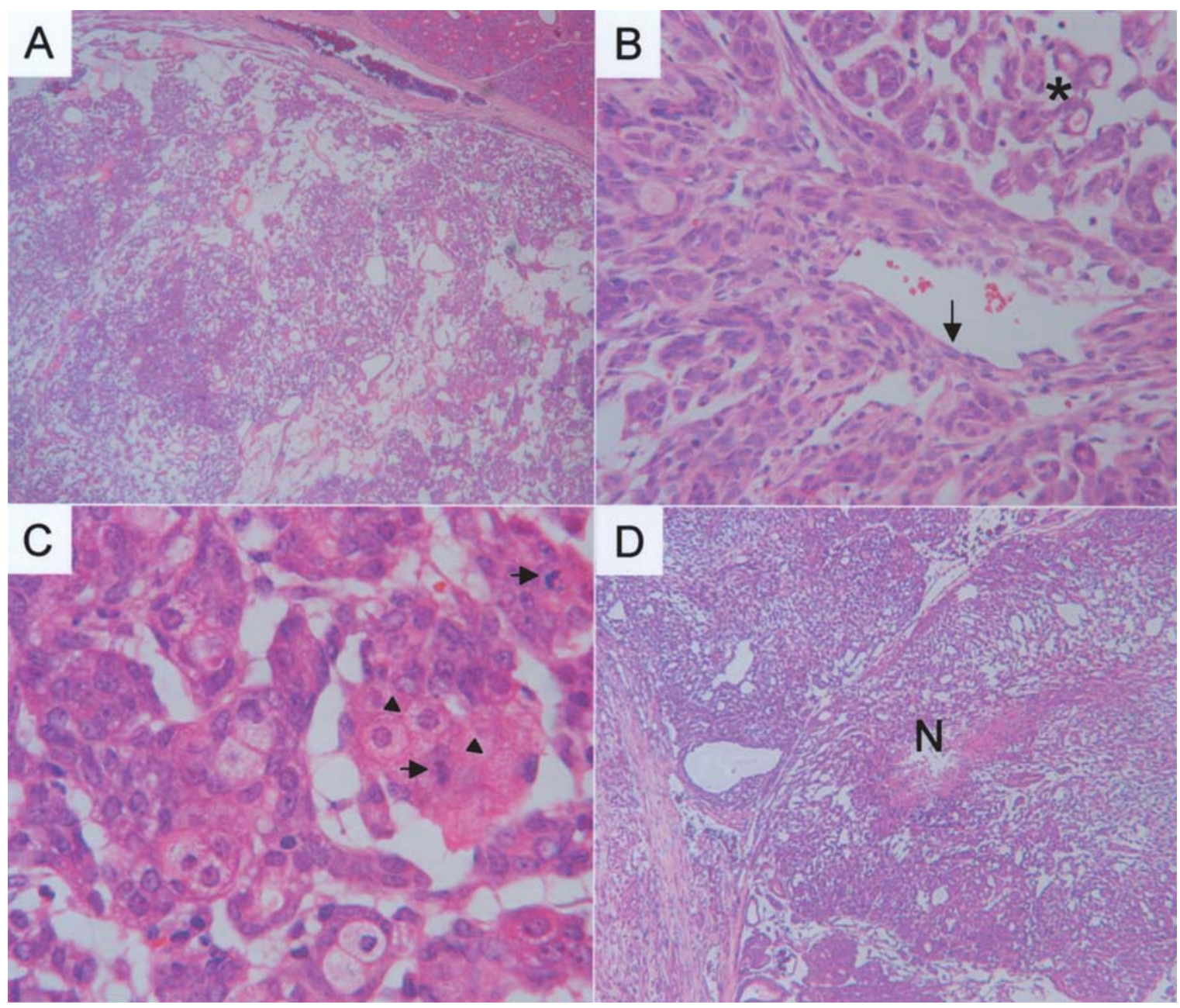

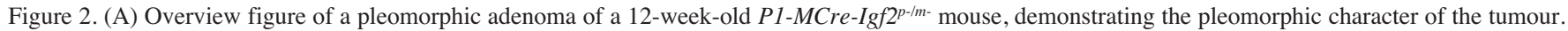
H\&E, original magnification of x2.5. (B) Pleomorphic adenoma of a 10-week-old P1-MCre-Igf $2^{p-/ m-}$ mouse, showing the presence of tubular structures (epithelial cells) (*) as well as spindle, myoepithelial cells (down arrow). H\&E, original magnification of x20. (C) Pleomorphic adenoma of a 12-week-old P1-MCre-Igf $2^{p-/ m-}$ mouse, showing sebaceous/squamous metaplasia (arrowhead) and mitotic figures (right arrow). H\&E, original magnification of $\mathrm{x} 40$. (D) Pleomorphic adenoma of a 22-week-old P1-MCre-Igf $2^{p-1 m-~ m o u s e, ~ s h o w i n g ~ m a l i g n a n t ~ c h a r a c t e r i s t i c s ~ s u c h ~ a s ~ t h e ~ p r e s e n c e ~ o f ~ a ~ n e c r o t i c ~ r e g i o n ~(N) . ~ H \& E, ~}$ original magnification of $\mathrm{x} 5$.

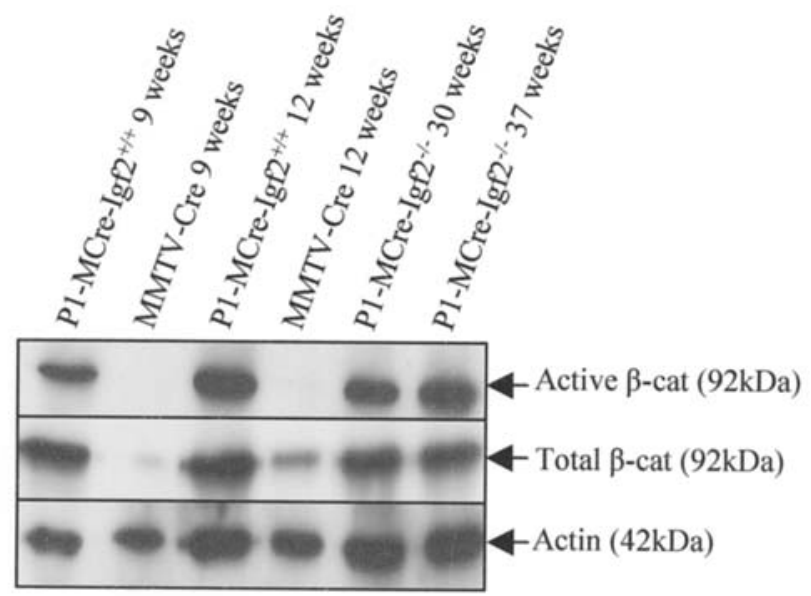

Figure 3 . The accumulation of $\beta$-catenin and active- $\beta$-catenin in pleomorphic adenomas of the salivary glands of 9- and 12-week-old P1-MCre-Igf $2^{p+/ m+}$ mice and 30- and 37-week-old P1-MCre-Igf $2^{p-/ m-}$ mice as compared to the levels in salivary glands of littermate MMTV-Cre mice was demonstrated by Western blot analysis, using different antibodies as described in Materials and methods. An anti-actin antibody was used to visualize equal loading. mice is illustrated in Fig. 2A. The tumours are composed of regions that contain mainly tubular structures (epithelial cells) and other regions that contain mainly spindle cells (myoepithelial cells) (Fig. 2B). Some of the tumours show sebaceous/squamous differentiation (Fig. 2C). In older tumours malignant features such as numerous mitotic figures (Fig. 2C) and necrotic regions (Fig. 2D) were observed. The same characteristics were found in pleomorphic adenomas of P1-MCre-Igf $2^{p+/ m+}$ mice (23).

Expression upregulation of PLAG1 target genes in P1-MCreIgf $2^{p-/ m-}$ mice. P1-MCre-Igf $2^{p-/ m-}$ mice still develop salivary gland tumours, although after a latency period that is about twice as long as in P1-MCre-Igf $2^{p+/ m+}$ mice. Therefore, it is reasonable to conclude that also other molecular pathways, besides Igf signalling, are involved in PLAG1-induced tumourigenesis. Previously, several other genes, such as H19, Dlk1, Gtl2, Igfbp2 and Igfpb3 have been found to be upregulated in PLAG1-induced tumours. In this study, their expression levels were investigated in $\mathrm{Pl}-\mathrm{MCre}-\mathrm{Ig} \mathrm{2}^{p-/ m}{ }^{-}$mice and compared to those in P1-MCre-Igf $2^{p+/ m+}$ mice (Table I). 
In this way, we wanted to see whether or not the expression of these genes is dependent on $I g f 2$ expression, and presumably Igf2 signalling. As might be expected, no expression of $I g f 2$ was observed when $I g f 2$ was inactivated in $\mathrm{P} 1-\mathrm{MCre}$ mice and the expression of $\mathrm{I} g \mathrm{f} 2$ was significantly decreased $(\mathrm{P}=0.02)$ in P1-MCre-Igf $2^{p-/ m-}$ mice.

The expression levels of all the other genes investigated were not significantly different in $\mathrm{Pl}-\mathrm{MCre}-\mathrm{Ig} f \mathrm{2}^{p-/ m-}$ mice as compared to littermate $P 1-M C r e-I g f 2^{p+/ m+}$ mice and are as such independent of $I g f 2$ expression. The $H 19$ gene of the imprinted gene cluster $I g f 2 / H 19$ is still significantly upregulated when both $I g f 2$ alleles are knocked out in P1-MCre mice. Similarly, the genes from the imprinted gene cluster $D l k 1 / G t l 2$ and the Igfbp 2 and $I g f b p 3$ genes are also significantly upregulated under those conditions. Zhao and co-workers reported about the involvement of Wnt signalling in PLAG1-induced pleomorphic salivary gland adenomas in non-inducible $M M T V$ PLAG1 transgenic mice (24). Therefore, we decided to investigate whether we could confirm this also in P1-MCre$\operatorname{Igf} 2^{p-/ m-}$ mice. Several genes involved in Wnt signalling, such as Wnt6, cyclin D1 and B-catenin, were found to be upregulated in Pl-MCre-Igf $2^{p-/ m-}$ and P1-MCre-Igf $2^{p+/ m+}$ mice. This upregulation was low and not significant for $\beta$-catenin in P1-MCre-Igf2 $2^{\text {p-lm- }}$ mice.

Wht signalling in pleomorphic adenomas of P1-MCre-Igf $2^{p+/ m+}$ and P1-MCre-Igf $2^{p-/ m-}$ mice. To further substantiate Wnt signalling in PLAG1-induced pleomorphic adenomas of the

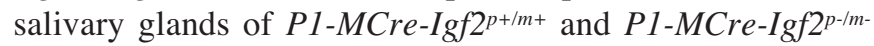
mice, Western blot analysis was performed. In absence of Wnt, GSK-3 is constitutively active and is believed to promote degradation of $\beta$-catenin by $\mathrm{N}$-terminal phosphorylation, ubiquitination, and proteasomal targeting subsequently. Upon Wnt signalling, the activity of GSK-3 is inhibited. As a consequence, $\beta$-catenin can no longer be phosphorylated and accumulates to form nuclear complexes with TCF/LEF transcriptional co-activators (36). In order to demonstrate the presence of active Wnt in PLAG1-induced pleomorphic adenomas of the salivary glands of Pl-MCre-Igf $2^{p+/ m+}$ and P1-MCre-Igf $2^{p-/ m-}$ mice, Western blot analysis was performed on pleomorphic adenomas of these mice and on control salivary glands of MMTV-Cre littermate mice. Accumulation of $\beta$-catenin in pleomorphic adenomas of P1-MCre-Igf $2^{p+/ m+}$ and P1-MCre-Igf2 $2^{p-l m-}$ mice was clearly demonstrated (Fig. 3). Furthermore, the presence of active- $\beta$-catenin was demonstrated in those pleomorphic adenomas, using a monoclonal antibody that specifically recognizes the non-phosphorylated residues Ser-37 and Thr-41 of $\beta$-catenin (36). Western blot analysis for actin was performed to demonstrate equal loading. These data all point towards the presence of active Wnt in the PLAG1-induced pleomorphic adenomas, independent of Igf2 expression.

\section{Discussion}

IGF signalling has been reported to be involved in many different human tumour types (31-35). Furthermore, the oncogenic capacity of $I G F-I I$ has been demonstrated in mouse models [reviewed by Werner and co-workers (37)]. For example, ectopic expression of $I G F-I I$ in the mammary glands leads to the development of mammary gland tumours after a long latency period $(38,39)$. In contrast, MMTV-IGF-II transgenic mice do not develop overt mammary and salivary gland tumours. Nevertheless, they do develop focal areas of epithelial hyperplasia in mammary glands as well as sporadic tumours in other organs, such as in the lungs. Overexpression of a constitutively active IGF-IR whose expression was driven by the MMTV-promoter resulted in rapid appearance of mammary and salivary gland tumours, further pointing towards a contributing role of IGF signalling in tumourigenesis. For those reasons, we decided to investigate the impact of Igf expression on PLAG1-induced tumourigenesis in the salivary glands, via inactivation of Igf2 in P1-MCre mice. The results clearly demonstrated an effect of Igf2 expression on PLAG1induced tumourigenesis. If $I g f 2$ is disrupted in P1-MCre mice, the appearance of macroscopically visible salivary gland tumours was delayed significantly. The latency period for tumour appearance about doubled. This observation suggests that Igf2 signalling in these PLAG1-induced tumours is similarly important as in the human salivary gland pleomorphic adenomas with PLAGI activation.

Given the above-suggested importance of Igf signalling in PLAG1-induced tumourigenesis, neutralization of Igf2 or other downstream components of this signalling pathway could be an effective therapeutic strategy in combination with other therapies to treat those tumours. Pharmacological antagonism of IGF ligands has been accomplished by neutralizing monoclonal antibodies (40-42). Most therapies target the IGF-IR (43). Several monoclonal antibodies, directed against IGF-IR $(44,45)$ and several small molecule inhibitors have been created $(46,47)$. Other therapies target factors even more downstream in the IGF-IR signalling pathway, such as mTOR signalling. mTOR inhibitors have shown promising clinical efficacy in subsets of cancers, with low toxicity profiles (48). In previous studies (22), we have shown that Igf-1r-NIH3T3 cells cannot be transformed in vitro by PLAG1. Therefore, the PLAG1 transgenic mouse model could constitute a tool to validate anti-cancer therapies that target Igf-1r in vivo in mice. Since the same molecular pathway also plays an important role in different human cancers, the generated data might have an impact relevant to many human cancers in case the data from the various mouse model systems that can be generated can be translated accordingly.

Since tumour development was not fully abrogated by inactivation of $I g f 2$, it is likely that additional signalling pathways contribute to PLAG1-induced tumourigenesis as well. Zhao and co-workers (24), previously demonstrated that Wnt signalling is involved in the formation of pleomorphic adenomas of the salivary glands in MMTV-PLAG1 transgenic mice. Immunohistochemical staining demonstrated that expression of $B$-catenin was highly upregulated with overexpression of the PLAG1 transgene in tumour and normal transgenic salivary gland tissue. They suggest that PLAG1 activates the transcription of mouse $\beta$-catenin in MMTV-PLAG1 transgenic mice. They demonstrated by luciferase experiments that PLAG1 can activate the mouse but not the human $B$-catenin promoter. As such, a direct upregulation of $\beta$-catenin in MMTV-PLAG1 transgenic mice is a plausible explanation for the possible involvement of 
Wnt signalling in PLAG1-induced pleomorphic adenomas in mice but not in humans. Nevertheless, also in human salivary gland pleomorphic adenomas WNT signalling seems to be implicated (49). One mechanism leading to the activation of the WNT signalling pathway in human pleomorphic adenomas is expected to be the downregulation of the WNT inhibitory factor 1 (WIF1).

In our studies, we provide evidence for the possible involvement of Wnt signalling in PLAG1-induced pleomorphic adenomas of the salivary glands in Pl-MCre-Igf $2^{p+/ m+}$ as well as $P 1-M C r e-I g f 2^{p-m-}$ mice. In contrast to Zhao and coworkers, we propose another mechanism involving Wnt-signalling in PLAG1-induced pleomorphic adenomas in mice. We establish that Wnt6 is significantly upregulated in PLAG1-induced pleomorphic adenomas as compared to normal salivary gland tissue of MMTV-Cre transgenic mice. As such, Wnt6 may bind to the frizzled receptor and activate Wnt signalling directly and not necessarily via upregulation of $\beta$-catenin itself. In contrast to the mechanism proposed by Zhao and co-workers, this mechanism might also be involved in human pleomorphic adenomas. Nevertheless, this hypothesis still needs to be confirmed in human pleomorphic adenomas of the salivary glands, which overexpress PLAG1.

In conclusion, we clearly demonstrate that Igf signalling is involved in PLAG1-induced pleomorphic adenomas of the salivary glands in mice. Inactivation of Igf2 in P1-MCre mice leads to a delay in tumour development. Furthermore, we also demonstrated that Wnt signalling might be involved in those tumours in P1-MCre mice as well as in P1-MCre mice in which Igf 2 is disrupted.

\section{Acknowledgements}

This work was supported in part by the Geconcerteerde Onderzoekacties (GOA) 2008/016, the 'Industrieel Onderzoeksfonds' (IOF) of the Flemish government, the 'Fonds voor Wetenschappelijk Onderzoek Vlaanderen' (FWO) grants G.0099.02, G.0441.06 and G.0234.07, the Cancer Research Program of Fortis Bank Insurance 2002-2005, the Foundation for Biochemical, Pharmacological Research and Education, and the Foundation against Cancer, foundation of public interest. J.D. is an aspirant fellow of the 'Fonds voor Wetenschappelijk Onderzoek Vlaanderen’ (FWO), whereas FVD is an aspirant fellow of the 'Institute for the Promotion of Innovation through Science and Technology in Flanders (IWT-Vlaanderen)'.

\section{References}

1. Speight PM and Barrett AW: Salivary gland tumours. Oral Dis 8: 229-240, 2002 .

2. Silvers AR and Som PM: Salivary glands. Radiol Clin North Am 36: 941-966, 1998.

3. Lee KC, Chan JK and Chong YW: Ossifying pleomorphic adenoma of the maxillary antrum. J Laryngol Otol 106: 50-52, 1992.

4. Olsen KD and Lewis JE: Carcinoma ex pleomorphic adenoma: a clinicopathologic review. Head Neck 23: 705-712, 2001.

5. Mizui T, Ishimaru JI, Miyamoto K and Toida M: Malignant transformation of a gigantic pleomorphic adenoma of the submandibular gland: a case report. J Oral Maxillofac Surg 58: $1422-1424,2000$.
6. Roijer E, Nordkvist A, Strom A-K, Ryd W, Behrendt M, Bullerdiek J, Mark J and Stenman G: Translocation, deletion/ amplification, and expression of HMGIC and MDM2 in a carcinoma ex pleomorphic adenoma. Am J Pathol 160: 433-440, 2002.

7. Sandros J, Stenman G and Mark J: Cytogenetic and molecular observations in human and experimental salivary gland tumors. Cancer Genet Cytogenet 44: 153-167, 1990.

8. Bullerdiek J, Raabe G, Bartnitzke S, Boschen C and Schloot W: Structural rearrangements of chromosome $\mathrm{Nr} 8$ involving 8q12: a primary event in pleomorphic ademona of the parotid gland. Genetica 72: 85-92, 1987.

9. Stenman G: Fusion oncogenes and tumor type specificity: insights from salivary gland tumors. Semin Cancer Biol 15: 224-235, 2005.

10. Schoenmakers EF, Wanschura S, Mols R, Bullerdiek J, Van den Berghe $\mathrm{H}$ and Van de Ven WJ: Recurrent rearrangements in the high mobility group protein gene, HMGI-C, in benign mesenchymal tumours. Nat Genet 10: 436-444, 1995.

11. Kas K, Voz ML, Roijer E, Astrom AK, Meyen E, Stenman G and Van de Ven WJ: Promoter swapping between the genes for a novel zinc finger protein and beta-catenin in pleiomorphic adenomas with $\mathrm{t}(3 ; 8)(\mathrm{p} 21 ; \mathrm{q} 12)$ translocations. Nat Genet 15 : 170-174, 1997.

12. Hensen K, Braem C, Declercq J, Van Dyck F, Dewerchin M, Fiette L, Denef C and Van de Ven WJ: Targeted disruption of the murine Plag1 proto-oncogene causes growth retardation and reduced fertility. Dev Growth Differ 46: 459-470, 2004.

13. Voz ML, Astrom AK, Kas K, Mark J, Stenman G and Van de Ven WJ: The recurrent translocation $\mathrm{t}(5 ; 8)(\mathrm{p} 13 ; \mathrm{q} 12)$ in pleomorphic adenomas results in upregulation of PLAG1 gene expression under control of the LIFR promoter. Oncogene 16: 1409-1416, 1998

14. Astrom AK, Voz ML, Kas K, Roijer E, Wedell B, Mandahl N, Van de Ven W, Mark J and Stenman G: Conserved mechanism of PLAG1 activation in salivary gland tumors with and without chromosome 8q12 abnormalities: identification of SII as a new fusion partner gene. Cancer Res 59: 918-923, 1999

15. Asp J, Persson F, Kost-Alimova M and Stenman G: CHCHD7PLAG1 and TCEA1-PLAG1 gene fusions resulting from cryptic, intrachromosomal 8q rearrangements in pleomorphic salivary gland adenomas. Genes Chromosomes Cancer 45: 820-828, 2006.

16. Astrom A, D'Amore ES, Sainati L, Panarello C, Morerio C, Mark J and Stenman G: Evidence of involvement of the PLAG1 gene in lipoblastomas. Int J Oncol 16: 1107-1110, 2000.

17. Hibbard MK, Kozakewich HP, Dal Cin P, Sciot R, Tan X, Xiao S and Fletcher JA: PLAG1 fusion oncogenes in lipoblastoma. Cancer Res 60: 4869-4872, 2000.

18. Morerio C, Rapella A, Rosanda C, Tassano E, Gambini C, Romagnoli G and Panarello C: PLAG1-HAS2 fusion in lipoblastoma with masked 8q intrachromosomal rearrangement. Cancer Genet Cytogenet 156: 183-184, 2005.

19. Zatkova A, Rouillard JM, Hartmann W, Lamb BJ, Kuick R, Eckart M, von Schweinitz D, Koch A, Fonatsch C, Pietsch T, Hanash SM and Wimmer K: Amplification and overexpression of the IGF2 regulator PLAG1 in hepatoblastoma. Genes Chromosomes Cancer 39: 126-137, 2004.

20. Castilla LH, Perrat P, Martinez NJ, Landrette SF, Keys R, Oikemus S, Flanegan J, Heilman S, Garrett L, Dutra A, Anderson S, Pihan GA, Wolff L and Liu PP: Identification of genes that synergize with Cbfb-MYH11 in the pathogenesis of acute myeloid leukemia. Proc Natl Acad Sci USA 101: 4924-4929, 2004.

21. Landrette SF, Kuo YH, Hensen K, Barjesteh van Waalwijk van Doorn-Khosrovani S, Perrat PN, Van de Ven WJ, Delwel R and Castilla LH: Plag1 and Plagl2 are oncogenes that induce acute myeloid leukemia in cooperation with Cbfb-MYH11. Blood 105: 2900-2907, 2005.

22. Hensen K, Van Valckenborgh IC, Kas K, Van de Ven WJ and Voz ML: The tumorigenic diversity of the three PLAG family members is associated with different DNA binding capacities. Cancer Res 62: 1510-1517, 2002.

23. Declercq J, Van Dyck F, Braem CV, Van Valckenborgh IC, Voz M, Wassef M, Schoonjans L, Van Damme B, Fiette L and Van de Ven WJ: Salivary gland tumors in transgenic mice with targeted PLAG1 proto-oncogene overexpression. Cancer Res 65: 4544-4553, 2005.

24. Zhao X, Ren W, Yang W, Wang Y, Kong H, Wang L, Yan L, $\mathrm{Xu} \mathrm{G}$, Fei J, Fu J, Zhang C and Wang Z: Wnt pathway is involved in pleomorphic adenomas induced by overexpression of PLAG1 in transgenic mice. Int J Cancer 118: 643-648, 2006. 
25. Wagner KU, McAllister K, Ward T, Davis B, Wiseman R and Hennighausen L: Spatial and temporal expression of the Cre gene under the control of the MMTV-LTR in different lines of transgenic mice. Transgenic Res 10: 545-553, 2001.

26. Wagner KU, Wall RJ, St-Onge L, Gruss P, Wynshaw-Boris A, Garrett L, Li M, Furth PA and Hennighausen L: Cre-mediated gene deletion in the mammary gland. Nucleic Acids Res 25: 4323-4330, 1997

27. Voz ML, Mathys J, Hensen K, Pendeville H, Van Valckenborgh I, Van Huffel C, Chavez M, Van Damme B, De Moor B, Moreau Y and Van de Ven WJ: Microarray screening for target genes of the proto-oncogene PLAG1. Oncogene 23: 179-191, 2004.

28. Voz ML, Agten NS, Van de Ven WJ and Kas K: PLAG1, the main translocation target in pleomorphic adenoma of the salivary glands, is a positive regulator of IGF-II. Cancer Res 60: 106-113, 2000.

29. DeChiara TM, Efstratiadis A and Robertson EJ: A growthdeficiency phenotype in heterozygous mice carrying an insulinlike growth factor II gene disrupted by targeting. Nature 345 : 78-80, 1990.

30. DeChiara TM, Robertson EJ and Efstratiadis A: Parental imprinting of the mouse insulin-like growth factor II gene. Cell 64: 849-859, 1991

31. Sachdev D and Yee D: The IGF system and breast cancer. Endocr Relat Cancer 8: 197-209, 2001.

32. Helle SI: The insulin-like growth factor system in advanced breast cancer. Best Pract Res Clin Endocrinol Metab 18: 67-79, 2004.

33. Hadsell DL and Bonnette SG: IGF and insulin action in the mammary gland: lessons from transgenic and knockout models. J Mammary Gland Biol Neoplasia 5: 19-30, 2000.

34. Tricoli JV, Rall LB, Karakousis CP, Herrera L, Petrelli NJ, Bell GI and Shows TB: Enhanced levels of insulin-like growth factor messenger RNA in human colon carcinomas and liposarcomas. Cancer Res 46: 6169-6173, 1986.

35. Martin DC, Fowlkes JL, Babic B and Khokha R: Insulin-like growth factor II signalling in neoplastic proliferation is blocked by transgenic expression of the metalloproteinase inhibitor TIMP-1. J Cell Biol 146: 881-892, 1999.

36. van Noort M, Meeldijk J, van der Zee R, Destree O and Clevers H: Wnt signalling controls the phosphorylation status of betacatenin. J Biol Chem 277: 17901-17905, 2002

37. Werner H and Le Roith D: The insulin-like growth factor-I receptor signalling pathways are important for tumorigenesis and inhibition of apoptosis. Crit Rev Oncog 8: 71-92, 1997.

38. Bates P, Fisher R, Ward A, Richardson L, Hill DJ and Graham CF: Mammary cancer in transgenic mice expressing insulin-like growth factor II (IGF-II). Br J Cancer 72: 1189-1193, 1995.

39. Pravtcheva DD and Wise TL: Metastasizing mammary carcinomas in H19 enhancers-Igf2 transgenic mice. J Exp Zool 281: 43-57, 1998.
40. Van Den Berg CL, Cox GN, Stroh CA, Hilsenbeck SG, Weng C-N, Mcdermott MJ, Pratt D, Osborne CK, Coronado-Heinsohn EB and Yee D: polyethylene glycol conjugated insulin-like growth factor binding protein-1 (IGFBP-1) inhibits growth of breast cancer in athymic mice. Eur J Cancer 33: 1108-1113, 1997.

41. Miyamoto S, Nakamura M, Shitara K, Nakamura K, Ohki Y, Ishii G, Goya M, Kodama K, Sangai T, Maeda H, Shi-Chuang Z, Chiba T and Ochiai A: Blockade of paracrine supply of insulinlike growth factors using neutralizing antibodies suppresses the liver metastasis of human colorectal cancers. Clin Cancer Res 11: 3494-3502, 2005.

42. Goya M, Miyamoto S, Nagai K, Ohki Y, Nakamura K, Shitara K, Maeda H, Sangai T, Kodama K, Endoh Y, Ishii G, Hasebe T, Yonou H, Hatano T, Ogawa Y and Ochiai A: Growth inhibition of human prostate cancer cells in human adult bone implanted into nonobese diabetic/severe combined immunodeficient mice by a ligand-specific antibody to human insulin-like growth factors. Cancer Res 64: 6252-6258, 2004.

43. Yee D: Targeting insulin-like growth factor pathways. Br J Cancer 94: 465-468, 2006.

44. Sachdev D, Li SL, Hartell JS, Fujita-Yamaguchi Y, Miller JS and Yee D: A chimeric humanized single-chain antibody against the type I insulin-like growth factor (IGF) receptor renders breast cancer cells refractory to the mitogenic effects of IGF-I. Cancer Res 63: 627-635, 2003.

45. Wang Y, Hailey J, Williams D, Lipari P, Malkowski M, Wang X, Xie L, Li G, Saha D, Ling WL, Cannon-Carlson S, Greenberg R, Ramos RA, Shields R, Presta L, Brams P, Bishop WR and Pachter JA: Inhibition of insulin-like growth factor-I receptor (IGF-IR) signalling and tumor cell growth by a fully human neutralizing anti-IGF-IR antibody. Mol Cancer Ther 4: 1214-1221, 2005.

46. Haluska P, Carboni JM, Loegering DA, Lee FY, Wittman M, Saulnier MG, Frennesson DB, Kalli KR, Conover CA, Attar RM, Kaufmann SH, Gottardis M and Erlichman C: In vitro and in vivo antitumor effects of the dual insulin-like growth factor-I/insulin receptor inhibitor, BMS-554417. Cancer Res 66: 362-371, 2006

47. Wittman M, Carboni J, Attar R, Balasubramanian B, Balimane P, Brassil P, Beaulieu F, Chang C, Clarke W, Dell J, Eummer J, Frennesson D, Gottardis M, Greer A, Hansel S, Hurlburt W, Jacobson B, Krishnananthan S, Lee FY, Li A, Lin TA, Liu P, Ouellet C, Sang X, Saulnier MG, Stoffan K, Sun Y, Velaparthi U, Wong H, Yang Z, Zimmermann K, Zoeckler M and Vyas D: Discovery of a (1H-benzoimidazol-2-yl)-1H-pyridin-2-one (BMS536924) inhibitor of insulin-like growth factor I receptor kinase with in vivo antitumor activity. J Med Chem 48: 5639-5643, 2005.

48. Thomas GV: mTOR and cancer: reason for dancing at the crossroads? Curr Opin Genet Dev 16: 78-84, 2006.

49. Queimado L, Lopes CS and Reis AM: WIF1, an inhibitor of the Wnt pathway, is rearranged in salivary gland tumors. Genes Chromosomes Cancer 46: 215-225, 2007. 